\title{
Hygiene and motivation factors of nursing work in a cardiology ward
}

\author{
Fatores higiênicos e motivacionais do trabalho \\ do enfermeiro em enfermaria de cardiologia \\ Factores higiénicos y motivacionales del trabajo \\ del enfermero en enfermaría de cardiología
}

\section{Carolina Bueno Somense ${ }^{a}$ \\ Erika Christiane Marocco Duran ${ }^{b}$}

\section{ABSTRACT}

The present study aimed to identify hygienic and motivational factors in the nursing work according to the Two-Factor Theory, as well as their relation with professional satisfaction/dissatisfaction. This exploratory-descriptive study involved nine nurses from the cardiology ward of a hospital in the interior of the State of São Paulo, between August and September 2013. A self-applied questionnaire was used, including open and closed questions. The data were categorized as hygienic and motivational. Results show the nurses' satisfaction with autonomy, work itself and teamwork, duties, content and responsibilities of the job. Dissatisfaction is related to career growth possibilities; work, political and administrative conditions at the institution, supervision and lack of institutional support. Satisfaction and dissatisfaction factors include relationships, acknowledgements and remuneration. Nurses'satisfaction is determined by multiple and often controversial factors.

Descriptors: Occupational health. Nursing. Motivation. Job satisfaction.

\section{RESUMO}

Objetivou-se identificar fatores higiênicos e motivacionais segundo a Teoria dos Dois Fatores na prática do enfermeiro, bem como a relação destes com a satisfação/insatisfação profissional. Estudo exploratório-descritivo, envolvendo nove enfermeiros da enfermaria de cardiologia de um hospital do interior paulista, no período entre agosto e setembro de 2013. Utilizou-se um questionário autoaplicável, composto por questões abertas e fechadas. Os dados foram categorizados em higiênicos e motivacionais. Os resultados mostram a satisfação dos enfermeiros com autonomia, trabalho individual e em equipe, deveres, conteúdos e responsabilidades do cargo. E insatisfação com possibilidade de crescimento, condições de trabalho, políticas e administração da instituição, supervisão e falta de apoio institucional. Fatores de satisfação e insatisfação como relacionamentos, reconhecimento e remuneração. A satisfação dos enfermeiros é determinada por múltiplos fatores, muitas vezes, controversos.

Descritores: Saúde do trabalhador. Enfermagem. Motivação. Satisfação no emprego.

\section{RESUMEN}

La finalidad fue identificar factores higiénicos y motivacionales del enfermero de acuerdo con la teoría de los dos factores, y también su relación con la satisfacción/insatisfacción profesional. Estudio exploratorio-descriptivo, involucrando a nueve enfermeros de la enfermaría de cardiología de un hospital del interior paulista, en el período de agosto y septiembre de 2013. Se utilizó un cuestionario autoaplicable, compuesto por cuestiones abiertas y cerradas. Los datos fueron categorizados en higiénicos y motivacionales. Resultados muestran la satisfacción de los enfermeros con autonomía, trabajo en sí y en equipo, deberes, contenidos y responsabilidades del cargo. Insatisfacción con posibilidad de crecimiento, condiciones de trabajo, políticas y administración de la institución, supervisión y falta de apoyo institucional. Factores de satisfacción e insatisfacción como relaciones, reconocimiento y remuneración. La satisfacción del enfermero la determina múltiples factores, muchas veces, controvertidos.

Descriptores: Salud laboral. Enfermería. Motivación. Satisfacción en el trabajo.
D0l: $\quad$ http://dx.doi.org/10.1590/19831447.2014.03.45772 


\section{口INTRODUCTION}

Nursing is engaged in care, teaching and management, providing services that are simultaneously consumed and produced, and cannot be stored and later marketed ${ }^{(1)}$. These processes that are simultaneously produced and consumed, comprise several actions ranging from promotion and protection of health to rehabilitation (1).

Therefore, taking into consideration this diversity of processes and activities, nurses will play their roles as productive members of society, and need to be motivated and satisfied to carry out to their jobs efficiently and to the required quality ${ }^{(2)}$. Thus, job satisfaction impacts the health of the nursing professional, the institution and the patients ${ }^{(3)}$. These workers are often exposed to mental burdens that result in dissatisfaction and lack of motivation ${ }^{(1,3)}$.

Regarding the meaning of motivation, it can be expressed as follows: "inclination or action driven by a motive (need)" ${ }^{\text {"(4:24), }}$, satisfaction, in turn, is defined as "satisfying or eliminating a need"(4:24). Thus, motivation is in the need itself and not in the means of satisfying it ${ }^{(4)}$.

In order to understand motivation, Herzberg's Two-Factor Theory, according to which the concept of human motivation is based on two factors: hygiene and motivation ${ }^{(5)}$.

Hygiene factors are associated with the workplace, representing what the institution usually offers to workers to motivate them ${ }^{(5)}$. However, these extrinsic factors are not responsible for motivating the professionals, being only associated to the action taken by the professionals to satisfy their needs ${ }^{(4)}$. They comprise physical conditions/ work environment (comfort), remuneration (salaries/benefits), political and administrative conditions at the institution, type/extent of supervision, interpersonal relations at different hierarchical levels, job security and regulations ${ }^{(2,4-5)}$. Such conditions prevent dissatisfaction, which explains the use of the word "hygiene" to describe the preventive nature of factors that cause dissatisfaction"(5). When neglected, these factors produce dissatisfaction, and when appropriate, they do not consistently and continuously increase satisfaction, that is, these factors do not cause positive satisfaction ${ }^{(5)}$.

Regarding the motivational factors, which are intrinsic to work, they meet the inner needs of the workers, and include the work itself, challenging and stimulating tasks, duties, contents and responsibilities of the job, achievement and recognition for these achievements, possibility of assigning responsibilities to others, professional growth/development, freedom to decide and act (autonomy), use of personal skills (creativity), determination and subsequent evaluation of objectives ${ }^{(2,4)}$. Unlike hygiene factors, motivation factors raise satisfaction, resulting in increased productivity, that is, these factors cause positive satisfaction. When insufficient, they lead to no satisfaction ${ }^{(5)}$

For Herzberg ${ }^{(4)}$ motivation is self-powered by a generator and, consequently, individuals do not need external stimuli to carry out their activities and will perform them on their own, to satisfy their needs ${ }^{(4)}$.

It is demonstrated then that the factors that lead to satisfaction are different and independent from those that lead to dissatisfaction ${ }^{(5)}$. Thus, the opposite of satisfaction is no satisfaction (and not dissatisfaction), just as the opposite of dissatisfaction is no dissatisfaction (not satisfaction) $)^{(4-5)}$.

For nursing professionals, the factors that cause satisfaction in the work environment involve enjoying the work, recognition, possibility of helping others and relationships in the workplace ${ }^{(6)}$. The motivation factors, in turn, comprise the work itself and the relationships ${ }^{(2)}$.

In view of the above, this study is aimed to identify the hygiene and motivation factors in nursing professional practice in a cardiology ward of a university hospital in the inland of the State of São Paulo.

\section{DETHODOLOGY}

Qualitative-quantitative, exploratory-descriptive study that allowed description, characterization and observation of the phenomenon.

Study conducted in the cardiology ward of Hospital de Clínicas of the State University of Campinas - UNICAMP. Nine of 13 nurses divided into three groups according to their work shifts participated in the study. Nurses that were away from work, on Holiday and who refused to participate were not included. Inclusion criteria were: graduate degree in nursing and working as a nurse hired by the institution.

A self-administered questionnaire was used for data collection in August-September 2013. The first part of the questionnaire characterized the population, and the second, composed of open and closed questions, was based on hygiene and motivation factors, perception of job satisfaction, as well as on situations experienced in the cardiology ward. The return of the completed questionnaire and one copy of the free informed consent duly signed was deemed acceptance of participation. Data analysis was performed using descriptive statistics with distribution in absolute and relative frequencies. The categorization of the data was based on the Two-Factor Theory, according to which the concept of human motivation is founded on hygiene and motivation factors, and then analyzed and discussed. 
Approval from the Research Ethics Committee of FCM/ UNICAMP, under protocol no 331.266/2013 was obtained, ensuring support by Resolution 466/12.

\section{RESULTS}

The sample was composed by nine nurses as follows: 01 (11.1\%) nurse hired by Unicamp's Foundation - Funcamp and the other 8 (88.9\%) nurses passed a public examination and were servants of Unicamp.

Table 1 shows the characterization of the sample. The mean age was 45.3 years (standard deviation $=12.7$ years), with the minimum age of 24 years and the maximum age of 64 years
Of the participants, five (55.6\%) had children, and two (22.2\%), another employment contract. The monthly income is around 8.2 minimum wages (ranging between six and 13).

Three (33.3\%) professionals were participating in courses, events and updating seminars.

The travel time to work was in average 54.4 minutes (the longest time was two hours and 20 minutes and the shortest, 10 minutes).

In average, the participants graduated 20 years and one month ago (graduated between the years 19772010). Finally, they have been working for the institution for 16 years and two months, in average (seven months to 26 years), and those who worked in the ward as nurses

Table 1 - Distribution of nurses according to gender, age, religion, marital status, work shift and university degree. UNICAMP, 2013.

\begin{tabular}{|c|c|c|c|}
\hline \multirow{2}{*}{ Variables } & \multirow{2}{*}{ Categories } & \multicolumn{2}{|c|}{ University Hospital } \\
\hline & & $\mathbf{N}$ & $\%$ \\
\hline \multirow{2}{*}{ Gender } & Female & 6 & $66.7 \%$ \\
\hline & Male & 3 & $33.3 \%$ \\
\hline \multirow{5}{*}{ Age } & $20-29$ & 2 & $22.2 \%$ \\
\hline & $30-39$ & 1 & $11.1 \%$ \\
\hline & $40-49$ & 1 & $11.1 \%$ \\
\hline & $50-59$ & 4 & $44.4 \%$ \\
\hline & $60-69$ & 1 & $11.1 \%$ \\
\hline \multirow{4}{*}{ Religion } & Catholic & 4 & $44.4 \%$ \\
\hline & Evangelical & 3 & $33.3 \%$ \\
\hline & Spiritualist & 1 & $11.1 \%$ \\
\hline & Did not answer & 1 & $11.1 \%$ \\
\hline \multirow{4}{*}{ Marital status } & Single & 5 & $55.6 \%$ \\
\hline & Married & 2 & $22.2 \%$ \\
\hline & Divorced & 1 & $11.1 \%$ \\
\hline & Other & 1 & $11.1 \%$ \\
\hline \multirow{3}{*}{ Work shift } & Morning & 2 & $22.2 \%$ \\
\hline & Afternoon* & 3 & $33.3 \%$ \\
\hline & Evening & 4 & $44.4 \%$ \\
\hline \multirow{4}{*}{ University degree } & BA degree & 6 & $66.7 \%$ \\
\hline & Graduation/ BA degree & 2 & $22.2 \%$ \\
\hline & Specialization & 1 & $11.1 \%$ \\
\hline & Total & 9 & $100 \%$ \\
\hline
\end{tabular}

Source: Research Data.

* Afternoon shift in the institution comprises working hours from 8:00 to 17:00 hours. 
have been performing their activities for around 10 years and five months (between five months and 24 years) indicating that these professionals have been working for a long time in the sector. It can be seen that 03 (33.3\%) of the nurses have been working for the same length of time, in the institution and in the ward that is, they have been working in the cardiology ward since they joined the institution.

The meaning of job satisfaction was determined, and nurses' perception was analyzed. It was found that for $26.7 \%$ of the professionals, the meaning was directly related to proper care; for $26.7 \%$, to recognition; for $20.0 \%$, to work conditions; to $13.3 \%$, to interpersonal relationships and for $13.3 \%$ to achievement.

The category proper care comprises carrying out the work with responsibility, quality and pleasure, developing the activities in the best possible way, while reaching the goals of improvement, maintenance and promotion of patients' health. The use of knowledge and skills, aimed at obtaining patient recovery, was also mentioned. It was found that care itself and the object of the nursing job, the patient, is related to the meaning of satisfaction with patient recovery.

Concerning the category recognition, the meaning was found to be associated to feelings of appreciation and gratitude for the activities performed, both by the staff and by the patients and their families. It also includes the recognition expressed by the institution in the payment of salaries and benefits.

Job satisfaction also showed meanings associated to work conditions, involving good infrastructure, material and human resource conditions, in a pleasant environment.

According to the nurses, satisfaction also comprises the category interpersonal relationships (between the nursing staff, the multiprofessional team, supervision, patients and family members) associated to a harmonious relationship, with peer interaction and cooperation. Finally, the meaning of job satisfaction includes the feeling of personal/professional fulfillment and the sense of accomplishment.

Satisfaction and dissatisfaction were also questioned regarding their current feelings towards work. It was found that 07 (77.8\%) of the nurses were satisfied and 02 (22.2\%) were dissatisfied. However, even among those satisfied, lack of recognition at work and of support by the institution, overload, lack of investment and professional devaluation were cited as factors that prevented full satisfaction. The longer the professional has been working at the institution and the shorter the travel time, the higher the degree of satisfaction: both with $80 \%$.
The nurses were asked to mark among 17 items, five items that generated most satisfaction and five that generated most dissatisfaction in the work in the ward (Table 2).

For analysis of priority related data, the following was established: priority one obtained weight 10, priority two obtained weight eight, priority three, weight six, priority four, weight four and priority five, weight two.

After multiplication by weight, the five job satisfaction factors (priority) were demonstrated: freedom to decide and act (autonomy) 42 points; work itself: 40 points; relationships, 38 points; remuneration, 30 points and duties, content and responsibilities of the job, 24 points. And the six factors of job dissatisfaction were: professional growth, 48 points; physical and environmental conditions of the work, 40 points; political and administrative conditions at the institution, 40 points; achievement and recognition, 32 points and the type/extent of supervision and remuneration, 24 points.

When evaluated in priority order, the items considered as generators of satisfaction remain the same, or else, relationship with co-workers represented $13.3 \%$ and ranks third.

Another aspect observed concerns remuneration. Despite the low number of references (6.7\%), it ranks fifth among the factors that cause job dissatisfaction.

For a better understanding and data analysis, the participants were asked to describe the situations experienced which contributed to the feeling of job satisfaction and dissatisfaction.

Thus, the categories that emerged for the situations that cause satisfaction are composed of: work itself (50.0\%); team work (25.0\%), autonomy (12.5\%) and recognition (12.5\%).

The category work itself involves situations of recovery, execution of complex procedures and hospital discharge. Regarding team work, there are feelings related to the need for the team to work for the patient, with responsibility and security. Regarding autonomy, the category that emerges is providing services with freedom and security. Finally, regarding recognition, valuation of the professional by the patient, institution, team and the establishment of ties is present.

When the nurses described the situations that caused more dissatisfaction than satisfaction, the categories emerged were work conditions (63.6\%), relationships (27.3\%) and lack of institutional support (9.1\%).

In the category work conditions, the lack of material and human resources, overload, coping with death and performing tasks that are not within their job description deserve mention. The dimension relationship involves fe- 
Table 2 - Distribution of the factors that cause satisfaction and dissatisfaction, according to frequency (N) and percentage (\%). UNICAMP, 2013.

\begin{tabular}{|c|c|c|c|c|c|}
\hline \multirow{2}{*}{ Variables } & \multirow{2}{*}{ Categories } & \multicolumn{2}{|c|}{ Satisfaction } & \multicolumn{2}{|c|}{ Dissatisfaction } \\
\hline & & $\mathbf{N}$ & $\%$ & $\mathbf{N}$ & $\%$ \\
\hline \multirow{8}{*}{$\begin{array}{l}\text { Hygiene } \\
\text { Factors }\end{array}$} & Physical and environmental conditions of the work & 2 & $4.4 \%$ & 6 & $13.3 \%$ \\
\hline & Remuneration (salaries, benefits) & 5 & $11.1 \%$ & 3 & $6.7 \%$ \\
\hline & Political and administrative conditions at the institution & 1 & $2.2 \%$ & 7 & $15.6 \%$ \\
\hline & Type/extent of supervision & 1 & $2.2 \%$ & 4 & $8.9 \%$ \\
\hline & Relationship with supervision & 2 & $4.4 \%$ & 3 & $6.7 \%$ \\
\hline & Relationship with co-workers & 6 & $13.3 \%$ & 2 & $4.4 \%$ \\
\hline & Job security & 2 & $4.4 \%$ & 0 & $0.0 \%$ \\
\hline & Regulations & 1 & $2.2 \%$ & 1 & $2.2 \%$ \\
\hline \multirow{10}{*}{$\begin{array}{l}\text { Motivation } \\
\text { Factors }\end{array}$} & Work itself & 5 & $11.1 \%$ & 0 & $0.0 \%$ \\
\hline & Challenging, stimulating tasks & 2 & $4.4 \%$ & 2 & $4.4 \%$ \\
\hline & Duties, content and responsibilities & 3 & $6.7 \%$ & 0 & $0.0 \%$ \\
\hline & Achievement and recognition & 2 & $4.4 \%$ & 5 & $11.1 \%$ \\
\hline & Possibility of assigning responsibilities to others & 0 & $0.0 \%$ & 0 & $0.0 \%$ \\
\hline & Professional growth & 2 & $4.4 \%$ & 7 & $15.6 \%$ \\
\hline & Freedom to decide and act (autonomy) & 6 & $13.3 \%$ & 1 & $2.2 \%$ \\
\hline & use of personal skills (creativity) & 4 & $8.9 \%$ & 0 & $0.0 \%$ \\
\hline & Determination and evaluation of the objectives & 1 & $2.2 \%$ & 4 & $8.9 \%$ \\
\hline & Total & 45 & $100 \%$ & 45 & $100.0 \%$ \\
\hline
\end{tabular}

Source: Research Data.

elings associated to lack of interaction and dialogue, competitiveness and conflicts. As for the lack of institutional support, it reflects the nurses' perception of the lack of stimulus to professional growth and devaluation.

\section{口DISCUSSION}

Regarding the profile of the study sample, there was a predominance of female individuals, which is similar to other studies involving nurses ${ }^{(7)}$. Regarding how long ago did the participants graduate in nursing, 33.3\% graduated between 16 and 25 years ago, and this long training period may have positive aspects such as greater experience and security, and negative aspects, such as less interest in improving their performance ${ }^{(8)}$. We observed a low participation rate in courses and events (33.3\%), corroborating the literature ${ }^{(9)}$. It was inferred that this low participation, especially in scientific events, may be partly associated to the nurse's perception of the lack of institutional support, emerging as a category related to dissatisfaction with $9.1 \%$.

The long time working in the same sector (10 years and five months in average) indicates job satisfaction ${ }^{(8)}$ and strengthens personal and professional ties. Also, it was found, that the longer the professional has been working at the institution, the higher the degree of satisfaction, in contrast with what was observed for nurses working on psychiatric wards ${ }^{(3)}$. According to international studies, nurses who reported emotional involvement in their work activities were more satisfied and less inclined to leave their current job (10-11).

Given the meanings assigned to job satisfaction, we obtained the following: nurses have pleasure in developing activities intrinsic to the nursing profession such as caring/assisting; Distance from patients and care-related activities results in dissatisfaction ${ }^{(8)}$. In turn, recognition of 
the professional actions performed will increase the self-esteem of the nurse ${ }^{(8)}$. This recognition was associated to financial compensation. So, the salary is considered a factor that generates dissatisfaction ${ }^{(12)}$. Also, double and triple work shifts, with such overload impacting direct patient care and the administrative process, lack of material resources, among others, are considered factors that result in dissatisfaction ${ }^{(3,12)}$. The literature stresses that a good relationship is used as a mechanism to solve problems ${ }^{(13)}$. However, in this study, for $27.3 \%$ of respondents relationship was found to be ambiguous, generating more dissatisfaction than satisfaction.

Analysis of the responses of nurses showed that for $66.7 \%$, the meaning of satisfaction was associated to factors inherent to work (care, recognition and achievement) and for $33.3 \%$ it was associated to extrinsic factors (relationship and work conditions). Inherent factors lead to satisfaction ${ }^{(6)}$. A study with nurses on the meaning of motivation showed a predominance of extrinsic factors that prevent job dissatisfaction, in contrast with the findings of the present study ${ }^{(14)}$.

In view of the above, the meanings of job satisfaction for nurses are related to proximity to the client, to the qualified exercise of care and the feeling of recognition and valuation. Thus, an environment that provides adequate work conditions and good interpersonal relationships is necessary to generate satisfactory results. It is important to stress that the categories assigned to the meanings of job satisfaction corroborate the categories and subcategories identified in another study involving different contexts of the nursing profession ${ }^{(15)}$.

Regarding the current job, $77.8 \%$ are satisfied ${ }^{(7)}$. However, overload and devaluation were reported ${ }^{(3)}$.

Analysis of the elements that generate satisfaction and their priority showed 106 points related to motivation factors (work itself; autonomy; use of own skills) and 68 associated to hygiene factors (remuneration; relationships). As for the elements that generate dissatisfaction, 80 points related to motivation factors (achievement and recognition, professional growth) and 128 related to hygiene factors (physical and environmental conditions of work; remuneration; political and administrative conditions at the institution and type/extent of supervision) were observed. Therefore, according to the Two-Factor Theory, extrinsic factors do not motivate, and only encourage the professionals to take action ${ }^{(2)}$. However, the predominance of intrinsic factors led to satisfaction ${ }^{(4)}$. There was a predominance of motivation factors associated to satisfaction, and hygiene factors associated to dissatisfaction.
So, for nurses, freedom to decide and act (autonomy) was identified as a key factor that generates satisfaction in our sample, which is consistent with other studies ${ }^{(7-8)}$.

Items such as the work itself, as well as duties, content and responsibilities inherent to the function and the use of own knowledge and skills were not identified as factors that cause dissatisfaction (frequencies and priorities). However, they were considered important factors of satisfaction. The activities inherent to the work process are performed with satisfaction, that is, the patient is a source of satisfaction ${ }^{(8)}$. This result confirms that the presence of motivation factors produces satisfaction ${ }^{(2)}$. Thus, the work itself is rewarding, because it makes it possible for the professionals to meet their aspirations(2).

Interpersonal relationships are considered an important factor of job satisfaction, which make the work pleasant and facilitate the resolution of disputes ${ }^{(16)}$. According to the Two-Factor Theory, interpersonal relationships, an extrinsic factor, will reduce dissatisfaction in the work environment. It will not ensure satisfaction ${ }^{(2,5)}$.

The remuneration factor was found to be ambiguous: for some nurses it generated satisfaction, and for others, dissatisfaction. This relationship contrasts with the literature findings, according to which salaries are related to dissatisfaction ${ }^{(7,12)}$. Despite being dissatisfied with their salaries, the nurses indicated that they joined the institution to obtain job security through public competitions. Thus, it is inferred that this fact may be present in our population, since $88.9 \%$ of them passed competitive examinations, and the salary if the fifth factor of dissatisfaction ${ }^{(12)}$. As a factor of satisfaction, this item ranks fourth. It is believed that satisfaction with remuneration can be associated to the feeling of recognition and not merely as an allowance, and, thus, can be considered a motivation factor for nurses. Two other categories related to job satisfaction that emerged were recognition and teamwork. Teamwork enhances the feeling of job satisfaction ${ }^{(17)}$. In a study performed with the purpose of identifying the views of health workers on the relevant factors in the workplace for the promotion of health, teamwork was indicated as a resource of internal communication and collaboration, as well as to improve individual and collective work activities ${ }^{(18)}$.

Recognition, in turn, is another controversial factor in this sample, since it is considered a source of dissatisfaction. However, since there were reports of situations that generate satisfaction, it is considered a key category.

Recognition is a motivation factor and, thus, generates satisfaction for the individuals $s^{(4)}$. Non recognition and devaluation generate dissatisfaction ${ }^{(11)}$. So, being noticed and valued is satisfactory for nurses ${ }^{(19)}$. 
Professional growth is considered a key factor of dissatisfaction. Again, according to the Two-Factor Theory, professional growth is considered an intrinsic motivation factor related to the challenging activities that confer meaning to work, generating satisfaction, not dissatisfaction. So, there is some disagreement in the results of this investigation regarding the theory ${ }^{(4)}$.

Also, when nurses were requested to talk about situations that cause dissatisfaction the category lack of institutional support emerged, especially in the sense of not favoring/stimulating professional growth. This lack of support is present in different contexts of the nursing activity ${ }^{(15)}$.

Improper work conditions, that is, insufficient and poor human and material resources, compel nurses to improvisation, resulting in overload and job dissatisfaction $^{(15,17)}$. Such work conditions impair the quality of the service rendered, and the nurses feel dissatisfied for failing to adequately meet the patient's needs and being unable to provide high quality services ${ }^{(20)}$. Consequently, improper work conditions cause nurses to be dissatisfied with the institution as a whole ${ }^{(20)}$. Also, political and administrative conditions at the institution and supervision generate dissatisfaction ${ }^{(3)}$.

Analysis of the responses of the nurses showed that the factors that lead to dissatisfaction can be the same factors that lead to satisfaction, and the existence or inexistence of these factors determines this relationship.

\section{口CONCLUSION}

Due to its complexity, job dissatisfaction is determined by various and even controversial factors within the same population. It is believed that this variability is explained because it involves human beings and their relationship with the institution.

In the present study, $77.8 \%$ of the nurses are satisfied with the work, and the factors that contribute to satisfaction are autonomy, work itself and teamwork, duties, content and responsibilities. The factors that generate dissatisfaction are professional growth, work conditions, political and administrative conditions at the institution, type/extent of supervision and lack of institutional support. Ambiguity was found in factors such as relationships, recognition and remuneration also emerged.

Considering again that such situations of dissatisfaction will impact the quality of care and analyzing the responses obtained, we understand that high-quality care is directly related to the institution's structure, as well as to the involvement between the staff members and support of supervision services.
Therefore, the contribution of this study lies in understanding the factors that satisfy the nurse in a specific sector, under the perspective of a theory still little explored in nursing Professionals with autonomy to make decisions and act are satisfied and create strategies to improve the work environment, with direct positive outcomes regarding care. Thus, the institutions should analyze the factors that impact job satisfaction/dissatisfaction, in an attempt to minimize dissatisfaction, maximizing the contribution of nurses to the success of their teams and the institution as a whole.

\section{QREFERENCES}

1. Benito GAV, Tristão KM, Paula ACSF, Santos MA, Ataide LJ, Lima RCD. Desenvolvimento de competências gerais durante o estágio supervisionado. Rev Bras Enferm. 2012 fev;65(1):172-8.

2. Pereira MCA, Fávero N. A motivação no trabalho da equipe de enfermagem. Rev Latino-Am Enfermagem. 2001 jul; 9(4):7-12.

3. Melo MB, Barbosa MA, Souza PR. Satisfação no trabalho da equipe de enfermagem: revisão integrativa. Rev Latino-Am Enfermagem. 2011 jul/ago;19(4):[09 telas].

4. Bergamini $\mathrm{CW}$, Coda R, organizadores. Psicodinâmica da vida organizacional: motivação e liderança. 2ed. São Paulo: Atlas; 1997.

5. Chiavenato I. Recursos humanos: edição compacta. 5. ed. São Paulo: Atlas; 1998.

6. Regis LFLV, Porto IS. Necessidades humanas básicas dos profissionais de enfermagem: situaçōes de (in)satisfação no trabalho. Rev Esc Enferm USP. 2011 abr;45(2):334-41.

7. Siqueira VTA, Kurcgant P. Satisfação no trabalho: indicador de qualidade no gerenciamento de recursos humanos em enfermagem. Rev Esc Enferm USP. 2012 fev:46(1):151-7.

8. Campos RM, Farias GM, Ramos CS. Satisfação profissional da equipe de enfermagem do SAMU/Natal. Rev Eletr Enf. 2009;11(3):647-57.

9. Martins C, Kobayashi RM, Ayoub AC, Leite MMJ. Perfil do enfermeiro e necessidades de desenvolvimento de competência profissional. Texto \& Contexto Enferm. 2006 jul-set; $15(3): 472-8$.

10. Carter MR, Tourangeau AE. Staying in nursing: what factors determine whether intend to remain employyed? J Adv Nurs. 2012;68(7):1589-600.

11. Tourangeau AE, Cummings G, Cranley LA, Ferron EM, Harvey S. Determinants of hospital nurse intention to remain employed: broadening our understanding. J Adv Nurs. 2010; 66(1):22-32.

12. Batista AAV, Vieira MJ, Cardoso NCS, Carvalho GRP. Fatores de motivação e insatisfação no trabalho do enfermeiro. Rev Esc Enferm USP. 2005;39(1):85-91.

13. Kessler Al, Krug SBF. Do prazer ao sofrimento no trabalho da enfermagem: 0 discurso dos trabalhadores. Rev Gaúcha Enferm. 2012 mar;33(1):49-55.

14. Bezerra FD, Andrade MFC, Andrade JS, Vieira MJ, Pimentel D. Motivação da equipe e estratégias motivacionais adotadas pelo enfermeiro. Rev Bras Enferm. 2010 jan-fev;63(1):33-7.

15. Lemos MC, Passos JP. Satisfação e frustração no desempenho do trabalho docente em enfermagem. REME: Rev Min Enferm. 2012 jan/mar;16(1):48-55.

16. Chaves $L D$, Ramos $L H$, Figueiredo EN. Satisfação profissional de enfermeiros do trabalho no Brasil. Acta Paul Enferm. 2011;24(4):507-13. 
17. Silveira RS, Funck CR, Lunardi VL, Silveira JT, Avila LI, Filho WDL, et. al. Percepção dos trabalhadores de enfermagem acerca da satisfação no contexto do trabalho na UTI. Enferm Foco (Brasília). 2012; 3(2):93-6.

18. Bringsén Å, Andresson HI, Ejlertsson G, Troeinb M. Exploring workplace related health resources form a salutogenic perspective: results form a focus group study among healthcare workers in Sweden. Work. 2012;42:404-14.
19. Garcia AB, Dellaroza MSG, Haddad MCL, Pachemshy LR. Prazer no trabalho de técnicos de enfermagem do pronto-socorro de um hospital universitário público. Rev Gaúcha Enferm. 2012 jun;33(2):153-159.

20. Nunes CM, Tronchin DMR, Melleiro MM, Kurcgant P. Satisfação e insatisfação no trabalho na percepção de enfermeiros de um hospital universitário. Rev Eletr Enf [Internet]. 2010;12(2):252-7. doi: dx.doi.org/10.5216/ree.v12i2.7006.

\section{Author's address:}

Erika Christiane Marocco Duran

Rua Tessália Vieira de Camargo, 126, Cidade Universitária Zeferino Vaz

13083-887, Campinas, SP

E-mail: ecduran@fcm.unicamp.br
Received: 19.03.2014

Approved: 28.07.2014 